\title{
Renewable Energy Production Potential by using from Wastes Generated in a Pigs Farm and Slaughterhouse
}

\author{
RUFIS TAGNE TIEGAM FREGUE ${ }^{1,2}$, ADRIANA RALUCA WACHTER ${ }^{2 *}$, IOANA IONEL ${ }^{2}$, TEODOR VINTILA ${ }^{3}$, CALIN JULEAN ${ }^{3}$, SEBASTIAN MOISA ${ }^{3}$, \\ CLAUDIU ION UNGUREANU ${ }^{1}$, ALIN CRISTIAN MIHAIUTI ${ }^{1}$ \\ ${ }_{1}^{1}$ Research Unit of Noxious Chemistry and Environ. Eng., Dep. of Chemistry, Faculty of Science, University of Dschang, P.O.Box 67, Dschang, \\ Cameroon \\ 2 Politehnica University of Timisoara, Mechanical Engineering Faculty, 1 Mihai Viteazu Blvd., 300222, Timisoara, Romania \\ ${ }^{3}$ University of Agricultural Science and Veterinary Medicine King Michael I of Romania from Timisoara - Department of Biotechnologies, \\ 119 Calea Aradului, Timisoara, Romania
}

\begin{abstract}
Biogas produced from wastes is regarded as advanced biofuel and is under current EU regulation, promoting the growth of advanced biofuels. In this study, the authors focused the research on the potential of a pig farm and an adjacent slaughterhouse and meat processing enterprise to produce not only meat, but energy as well, through anaerobic digestion of wastes produced during current activities to produce biogas as energy carrier. One had assessed the potential of a pig's farm and an adjacent slaughterhouse and meat processing enterprise to produce biogas as energy carrier, using anaerobic digestion of wastes generated in production activity. All experiments were carried out on a performing lab device. The results indicate solid sludge and fats resulted from slaughterhouse are capable to produce high yields of methane, reported to dry organic matter. Although organic wastes resulted from slaughterhouse can generate high quantities of methane by anaerobic digestion, large quantities of organic wastes are generated in the assessed pig's farm and the potential for energy production is much higher in the case considering as source the pig's farm than slaughterhouse. Finally, one demonstrated that by combining organic wastes generated in the pig's farm with the organic wastes resulted from slaughterhouse, or organic wastes generated in the pig's farm with the biomass produced on 200 hectares of triticale as short rotation crop, one can supply the energy source, necessary to operate an one-megawatt installed power biogas plant.
\end{abstract}

Keywords: renewable energy, biogas, organic wastes

Green energy will be the core of post-petroleum societyand the biobased economy. Despite all controversies, biofuels do and will continue to constitute a major share in green energy sector. Advanced biofuels representall solid, liquid and gaseous combustible materials generated from biological non-feed and non-food renewable resources. Organic waste materials are primarily considered to contain huge unused potential to be converted in green energy. Burning materials containing large quantity of water is not economically efficient, or in terms of energy balance.

Biological conversion processes, as fermentation or anaerobic digestion (AD) have numerous advantages, such as: high energy balance, low carbon emissions, in many cases produces no wastes, high economic efficiency, positive social impacts in rural areas etc.

Anaerobic digestion has even more particular advantages, as it is a natural process, made by microorganisms presenton Earth since early times of beginning of live, it uses existent microbial biodiversity, there is no necessity to genetically alter microorganisms involved in this process, once inoculated - the process runs theoretically forever if process parameters and feeding rate are well controlled. Anaerobic digestion is probably the most appealing process to be applied in agricultural farms in order to convertorganic wastes produced during farming activities into energy and - not less important - into organic fertilizer.

In this study, we have assessed the potential of a pigs farm and an adjacent slaughterhouse and meat processing enterprise to produce not only meat, but energy as well, through anaerobic digestion of wastes produced during currentactivities to produce biogas as energy carrier. Biogas produced from wastes is regarded as advanced biofuel and is under currentEU regulation promoting the growth of advanced biofuels. In January 17th 2018 EU Parliament adopted RED II (Renewable Energy Directive), by which all EU countries mustensure that at least $10 \%$ of their transportfuels come from renewable sources by 2020 and that minimum share of advanced biofuels to be gradually increased from at least $0.5 \%$ in 2021 to at least $3.6 \%$ in 2030 [1].

\section{Experimental part}

Materials and methods

The organic wastes were sampled and investigated in the Laboratory of Industrial Microbiology and Biotechnologyfrom University of Agricultural Science and Veterinary Medicine King Michael I of Romania from Timisoara. The first analyses were made to establish dry mater content and organic load. Based on the results, suitable

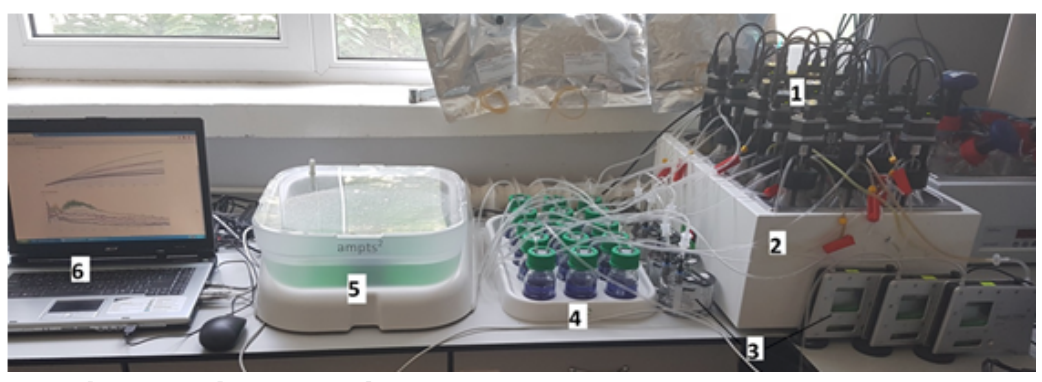

Fig. 1. General overview of AMPTS system:

1- bioreactors/digesters, 2- incubation unit, 3- gas counters, 4- $\mathrm{CO}_{2}$ absorption unit, 5- methane measuring unit, 6 - laptop for data recording 
recipes for anaerobic digestion (AD) were calculated, and were subjected to AD process by using AMPTS II laboratory equipment, in order to point out the Biochemical Methane Potential (BMP) of the sampled organic materials. The conversion of biomass to biogas was tested according to the widely accepted German standard protocol VDI $4630[2]$.

\section{Sampling and investigation}

Sampling, sample transportation and conservation as well as sample preparation are integral components of the testing digestion of organic materials and exercise a decisive influence upon the quality of the results. All sampling procedures for the investigated organic materials (substrates) were conducted according to standard methods [2-5]. For fermentation tests seeding sludge was used as inoculum, provided from a large scale biogas plant.

Samples were collected from a pigfarm and from a slaughterhouse, as follows:

1-Animal fats from slaughter house (AF)

2-Waste-water from slaughter house pumping station (WW)

3 -Solid sludge from slaughter house (SS)

4-Pigs slurry from storage tank (PST)

5 -Pigs slurry from pumping station (PSP)

6 -Triticale silage (energy biomass, as control) (TS)

7 -Inoculums -harvested from a functional on-farm biogas plant (I).

Previous to $A D$ experiment set up, it is necessary to investigate the dry solids (DS) and volatile solids (VS) of substrates. The dry matter, i.e. all inorganic and organic compounds, is expressed as DS and was measured according to standard protocols, by keeping samples $24 \mathrm{~h}$ on $105^{\circ} \mathrm{C}$ in order to remove all water content [2, 3].

The VS is represented by organic compounds in the sample. After completing the DS measurements, heating the sample up to $550^{\circ} \mathrm{C}$ for 2 hours, it was necessary to burn up the organic matter. The weight difference between the sample after heating at $105^{\circ} \mathrm{C}$ and $550^{\circ} \mathrm{C}$ indicates the VS content of the substrate [3].

Laboratory equipmentused isan Automatic Methane Potential Test System-AMPTSII, developed by Bioprocess Control Sweden AB (BPC), which has 15 digesters of $600 \mathrm{ml}$ total volume. For high accuracy experimental datarecords, the BMP (Biochemical MethaneProduction) investigated for each sample was achieved as triplicates, according to BPC protocol [4].

The investigated samples and quantities used in the present experiment were prepared according to standard protocol VDI4630 and $\mathrm{BPC}[2,4]$.

The general overview of the laboratory equipment is presented in figure 1. The batches were subjected to mesophilic digestion, at incubation temperature of $37^{\circ} \mathrm{C}$. Before the beginning of the incubation, all 15 bioreactors were flushed for approx. $60 \mathrm{~s}$ with a gas mixture of $45 \% \mathrm{CO}_{2}$ and $55 \% \mathrm{~N}$ by volume. The digestion process is ended when the biogas yield decreases less than $1 \%$ (by volume) from the total biogas yield.

\section{Results and discussions}

The decision whether organic residues resulted in pigs farming and meat processing can be converted by anaerobic digestion to produce methane at large scale is dependent by the results obtained in laboratoryscale, in the biochemical methane production (BMP) test carried out in this AMPTSII system. The results provided by this testare proved to be very reliable and the method is applied world-wide to establish the amountmethane released during anaerobic digestion of organic matter $[6,7]$. The volume of methane generated in BMP testis expressed in units of volume in standard temperature and pressure conditions, i.e. $0^{\circ} \mathrm{C}$ (or 32०F) and $1.013 \mathrm{bar}$ (or $14.69 \mathrm{psi}$ ). These reference conditions are stated as normal conditions and are indicated by underlying letter $N$ in the unit of volume used (e.g. $\mathrm{m} /$ ). Knowing the energy density of methane, the BMP test is used to establish the amount of methane and consequentytheenergy produced in mixtures of several organic substrates. This calculation can be used to establish the amount of incentives offered in cases of energy production from waste materials versus dedicated crops etc.

In Romania, the support scheme, in the frame of green energy legislation establish differentnumbers of green certificates to begranted for biogas plants producing electricity [8]. The biogas plants producing electricity from energy crops are granted with one extra green certificate per each $1 \mathrm{kWh}$ delivered to the grid if compared with the biogas plants producing electricity from wastes [9].

One recommends to the biogas producers to analyze and establish byBMP test the potential amount of bio-energy produced from wastes and from energy crops. The results can be delivered to the energy authority, which establish the amount of green certificates provided to the biogas producer, according to amount of bio-energy $[9,10]$.

The results regarding preliminary analyses of pigs wastes used in our study, inoculums and triticale as an example of short-period energy crop are presented in table 1.

Table 1

PROPERTIES OF INVESTIGATED SUBSTRATES, BY WEIGHT

\begin{tabular}{|c|c|c|c|c|c|}
\hline No & $\begin{array}{c}\text { Sample } \\
\text { ID }\end{array}$ & DS \% & $\begin{array}{c}\text { Ash, \% } \\
\text { from } \\
\text { DS }\end{array}$ & $\begin{array}{c}\text { VS, \% } \\
\text { from DS }\end{array}$ & $\begin{array}{c}\text { VS, \% } \\
\text { from } \\
\text { total }\end{array}$ \\
\hline 1 & AF & 7.32 & 3.47 & 96.53 & 7.07 \\
\hline 2 & WW & 1.00 & 13.33 & 86.67 & 0.87 \\
\hline 3 & SS & 18.30 & 13.29 & 86.71 & 15.87 \\
\hline 4 & PST & 3.41 & 30.8 & 69.2 & 2.36 \\
\hline 5 & PSP & 10.90 & 17.51 & 82.49 & 8.99 \\
\hline 6 & TS & 29.00 & 6.92 & 93.08 & 26.99 \\
\hline 7 & I & 6.62 & 22.50 & 77.50 & 5.13 \\
\hline
\end{tabular}

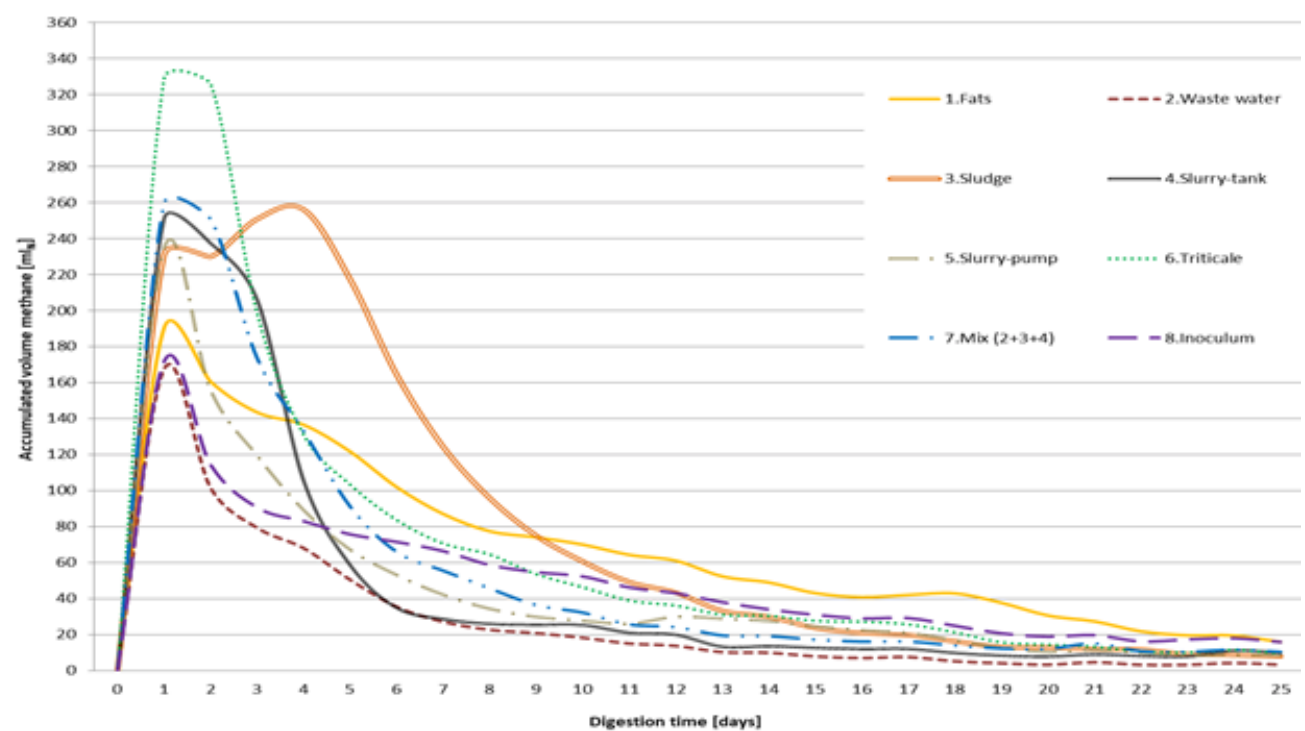

Fig. 2. Methane yields during anaerobic digestion 
By using the $\mathrm{CO}_{2}$ absorption unit (fig. 1), data recorded represents gas volume of $\mathrm{CH}_{4}^{2}$ recorded in milliliters under normal conditions $\left(\mathrm{mL}_{\mathrm{N}}\right)$. These data represent the average values of daily methane production of methane generated in each triplicate consisting of three $600 \mathrm{~mL}$ digesters containing $400 \mathrm{~mL}$ digestion medium. The inoculum / substrate ratio in all batches was 2:1, in terms of volatile solids. For a clearer picture regarding flow rates and gas methane dynamics, the recorded data are plotted in the graph in figure 2 .

Data in figure 2 reveal a high production of biogas when the mixture of energy crop and inoculum from a large-scale biogas plantis used as substrate (triticale silage). Organic wastes generated in both locations - pigs farm and abattoir produce important quantities of methane although lower than energy crop used as control.

When data generated in the laboratory scale digesters are used in BMP test, methane yields are reported to mass of organic matter. BMP test is a simple batch assay developed to determine the methane production of a given organic substrate during its anaerobic decomposition. BMP is defined as the volume of themethane produced per amount of organic substrate material added to the bioreactor, subtracting the methane generated by the inoculum $[4,11]$.

From BMP calculations for each type of substrate data resulting indicate the highestmethane yields in solid sludge and fatty residues generated in abattoir. The late substrate generates similar yields as energy crop triticale (fig. 3).

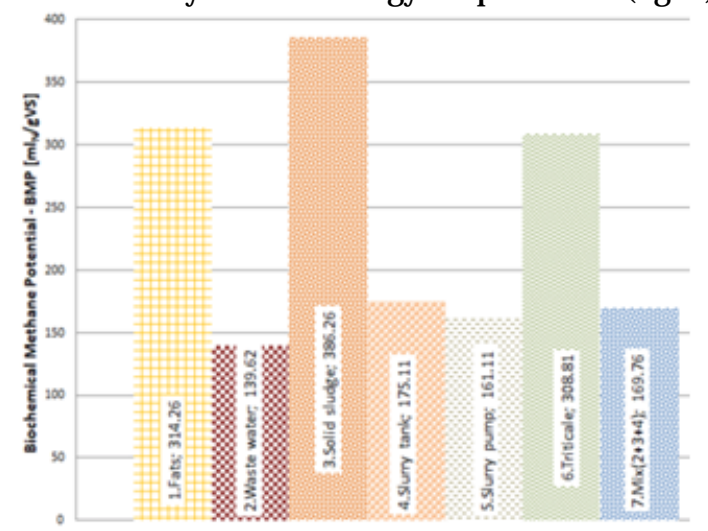

Fig. 3. BMP from different yields

By comparing data presented in figures 2 and 3 , one might be tented to conclude that some inadvertences are resulting.

It can be observed that despite of the high BMP potential of fats substrate, the methane generation in fats batch digester is much lower than in the case of the pig slurry or mixture.

These differences are due to the dilutions necessary to be done when feeding digesters with certain amounts of organic loads.

\section{Economic aspects}

The results generated by the laboratory tests and further analyses and calculations were used to quantify the amount of energy to be generated on-site.

The calculation is based on quantities of organic materials generated during a 12 months period, most of data being provided by the companyoperatingthe pigs farm and the slaughter house. Following conclusions are resulting:

1.In the case of Fatsubstrate, the farmer hasno possibility to provide exact quantity generated during 12 months activity. In this case, we calculated the amount of energy to be generated by 10 tons of fatty residues resulted from slaughter house activities. If the quantity can be assumed by the farmer to a closer range, the calculation can be easily corrected.

2.In case of energy crops (triticale silage), the authors' assumption provide data useful to compare the energy to be produced when 100 or 200 hectares of agriculture land is cultivated with a crop able to store a medium quantity of energy in shortime (itcan be cultivated as short rotation crop). One didn't proposed and used high-energy production crop, such as corn silage, because this culture needs agriculture land for an entire production cycle. Also better usage for this com is known, as food.

Data generated in the research and presented in table 2 indicate thatthe organic fraction generated during one year of activityin slaughter house can generate similar amount of energy if is an aerobically digested comparing to the energy that can be obtained from 200 hectares of land cultivated with energy crops (in this case triticale).

Regarding organic wastes generated in the farm, our results indicate triple amount of energy obtainable by converting these materials to methane, comparing to organic wastes from slaughter house. According to data in table 2, the necessary installed power of a suitable cogeneration heat and power unit (CHP) to convert the annual energy for 8400 working hours per year can be calculated. Subsequently, the scenarios in table 3 can be considered.

Table 2

ANNUAL ENERGY PRODUCTION

\begin{tabular}{|c|c|c|c|c|c|}
\hline $\begin{array}{c}\text { Sample } \\
\text { ID }\end{array}$ & $\begin{array}{c}\mathrm{BMP} \\
\left.\left[\mathrm{ml}_{N} / \mathrm{gVS}\right]\right]\end{array}$ & $\begin{array}{l}\text { Amount } \\
{[t / y]}\end{array}$ & VS [t/y] & $\underset{\left[\mathrm{m}^{3} \mathrm{~N} / \mathrm{y}\right]}{\mathrm{CH}_{4}}$ & $\begin{array}{l}\text { Energy } \\
\text { [MWh]* }\end{array}$ \\
\hline $\mathrm{AF}$ & 314.26 & 10 & 0.71 & 222 & 2.2 \\
\hline WW & 139.62 & 165174 & 1431.5 & 199880 & 1999 \\
\hline SS & 386.26 & 2640 & 418.91 & 161809 & 1618 \\
\hline \multicolumn{4}{|c|}{ Total from the slaughter house } & 361911 & 3619 \\
\hline PST & 175.11 & 95000 & 2241.73 & 392545 & 3925 \\
\hline PSP & 161.11 & 95000 & 9577.34 & 1542984 & 15430 \\
\hline \multicolumn{4}{|c|}{ Total from the Pigs Farm } & 1542984 & 15430 \\
\hline \multicolumn{4}{|c|}{ Total from the slaughter house + Farm } & 1904895 & 19049 \\
\hline TS & 308.81 & 4000 & 1079.7 & 333430 & 3334 \\
\hline \multicolumn{4}{|c|}{$\begin{array}{l}\text { Total from the slaughter house }+ \text { Farm }+ \\
\text { Energy crops }\end{array}$} & 2238325 & 22383 \\
\hline
\end{tabular}

Table 3

INSTALLED POWER OF CHP UNITS NECESSARY TO CONVERT THE BIOGAS INTO POWER AND THERMAL ENERGY

\begin{tabular}{|l|c|c|c|c|}
\hline \multicolumn{1}{|c|}{ Scenario } & $\begin{array}{c}\mathrm{CH}_{4} \\
{\left[\mathrm{~m}^{3} \mathrm{~N} / \mathrm{y}\right]}\end{array}$ & $\begin{array}{c}\text { Energy from } \\
\text { biogas [MWh] }\end{array}$ & $\begin{array}{c}\text { Electric energy } \\
{[\mathbf{M W h}]^{* *}}\end{array}$ & $\begin{array}{c}\text { CHP installed } \\
\text { power, kWe }\end{array}$ \\
\hline $\begin{array}{l}\text { 1. Slaughter house residues are converted on- } \\
\text { site }\end{array}$ & 361911 & 3619 & 1448 & 172 \\
\hline 2. Pigs farm residues are converted on-site & 1542984 & 15430 & 6172 & 735 \\
\hline $\begin{array}{l}\text { 3. Residues from the slaughter house are } \\
\text { transported to the pigs farm and converted } \\
\text { on-farm }\end{array}$ & 1904895 & 19049 & 7620 & 907 \\
\hline $\begin{array}{l}\text { 4. Addition of biomass from 100 hectares of } \\
\text { triticale to residues from pigs farm }\end{array}$ & 1876415 & 18764 & 7506 & 894 \\
\hline $\begin{array}{l}\text { 5. Addition of biomass from 200 hectares of } \\
\text { triticale to residues from pigs farm }\end{array}$ & 2209845 & 22098 & 8839 & 1052 \\
\hline \multirow{2}{*}{$\mathbf{4 0} \%$ conversion rate } & & & \\
\hline
\end{tabular}


The scenarios in table 3 presenta clear view regarding the potential of energy production from organic residues by anaerobic digestion. Our assessment indicates that conversion on-site of diluted abattoir residues is notan efficientoption, as high capital and operational costs are needed to convertlarge quantity of diluted waste-water to produce low quantity of energy.

A more efficient option is to transport the separated sludge and fats from the waste water treatment plant (w.w.t.p.) of the slaughterhouse to the pigs farm (scenario 3 ) and convert the mixture of farm wastes and w.w.t.p. sludge and fats to biogas. The conversion can be made in simple digesters as covered lagoons or mixed and covered storage tanks.

A close-range quantity of energy (enough to feed a $900 \mathrm{~kW}$. CHP unit) can be obtained if ensiled triticale obtained from around 100 hectares of land is added to the digester containing the organic wastes from pig farm. A surface of around 200 hectares of agricultural land cultivated with triticale as catch-crop (short rotation crop) is sufficient to be added to organic wastes from pigs farm to feed a one-megawatt CHP unit.

Furthercalculations can be carried outif additional data are provided by the farmer:

-one-year energy demands of the farm / abattoir as electricity and thermal energy equivalent as natural gas consumption. These data can be compared to the expected energy production rate by $A D$ process.

-acquisition price of the energy, in order to be compared to the estimated production costs of the energy by $A D$.

Finally the investments costs and annual costs can be calculated for a CHP unit dimensioned in accordance to the EU procedures for financial of agricultural biogas projects.

Primary Energy Savings (PES) indicators can be calculated in accordance to the EU legislation protocols. The annual income and savings can be established in differentpossible scenarios for the energy recovery [17]. Annual incomes can be calculated in correlation to total annual costs and annual savings. Byanalyzing the PES indicator values, different scenarios could be tailored to find out if, according to the EU legislation, the energy is produced in high efficiency unit $[18,19]$. This factdecides if an investmentinto biogas plantis eligible for EU funding ornot

\section{Conclusions}

One has evaluate the potential of a pig's farm and an adjacent slaughterhouse and meat processing enterprise to produce biogas that can be used as energy carrier, by using anaerobic digestion of wastes generated in the mentioned production activities.

The results indicate that solid sludge and fats resulted from slaughterhouse are producing high yields of methane reported to dry organic matter.

Large quantities of organic wastes are generated in the assessed pig's farm and the potential for energy production is much higher in the case of pig'sfarm than in the case of using wastefrom the slaughterhouse.

Combining (1) organic wastes generated in the pig's farm with the organic wastes resulted from slaughterhouse, or (2) organic wastes generated in the pig'sfarm with the biomass produced on 200 hectares of triticale as short rotation energy crop, one can supply the feedstock necessary to operate an one-megawattinstalled power biogas plant

Thusa waste producer can turn into an energy producer, mainlythe energy being used for internal necessities.

Acknowledgement: This work was concluded by Adriana Raluca Wachter, in herposition as PhD studentat the Politehnica University of Timisoara. The university is acknowledged for the support Many thanks to the staff of the Pig Farm (Smithfield) for all information and testingmaterials provided during the research for the presentpapers.

\section{References}

1.*** IEA, World Energy Statistics, OECD/IEA, 2014. http:// www.europarl. europa.eu/sides/getDoc.do?pubRef=-//EP//TEXT+TA+P8-TA2018-0009+0+DOC+XML+V0//EN, Amendments adopted by the European Parliament on 17 January 2018 on the proposal for a directive of the European Parliament and of the Council on the promotion of the use of energy from renewable sources.

REV.CHIM.(Bucharest) $70 \bullet$ No. $6 \bullet 2019$

http://www.revistadechimie.ro
2.*** ASSOCIATION OF GERMAN ENGINEERS, VDI 4630-Fermentation of Organic Materials: Characterization of the Substrate, Sampling, Collection of Material Data, Fermentation Test, (2006).

3.*** DIN-38414(S8), German Standard Methods for the Examination of Water, Waste Water and Sludge - Single Components (Group P), (2000).

4.*** BIOPROCESS CONTROL AB, Automatic Methane Potential System -AMPTS II, Operation and maintenance manual, (2016), 6465.

5.C. ONET, A. TEUSDEA, A. ONET, E. PANTEA, N.C. SABAU, V. LASLO, T. ROMOCEA, E. AGUD, Comparative study of dairy and meat processing wastewater characteristics, Journal of Environmental Protection and Ecology 19, no. 2, 508-514, 2018.

6.C. HOLLIGER, M. ALVES, D. ANDRADE, I. ANGELIDAKI, S. ASTALS, U. BAIER, C. BOUGRIER, P. BUFFIERE, M. CARBALLA, V. DE WILDE, et al. Towards a standardization of biomethane potential tests. Water Sci Technol., 74 (11), 2515-22, 2016.

7.R. M. JINGURA, R. KAMUSOKO, Methods for determination of biomethane potential of feedstock: a review, Biofuel Research J ournal, 14, 573-586, 2017.

8.*** Legea nr. 220 din 27 octombrie 2008 pentru stabilirea sistemului de promovare a producerii energiei din surse regenerabile de energie. (Law 220 from 27 October 2008 to establish energy promotion system from renewable resources). 9.*** Legea 139/2010 privind modificarea si completarea Legii $\mathrm{nr}$. 220/2008 pentru stabilirea sistemului de promovare a producerii energiei din surse regenerabile de energie. (Law 139/2010 regarding amendments and addendum to Law 220/2008 to establish energy promotion system from renewable resources).

10.M. MATIUTI, A.T. BOGDAN, D. DIACONESCU, C.L. MATIUTI, Agroecological parks, an innovative solution based on bio-ecoeconomy for sustainable rural development and environmental preotection in the Banat Euroregion, Studies and research in etnozootechny, animal biodiversity and bioeconomy, Vol. 1, 180183, 2018.

11.*** Fachagentur Nachwachsende Rohstoffe e.V. with support of Federal Ministry of Food, Agriculture and Consumer Protection, Guide to Biogas -From production to use. $5^{\text {th }}$ completely revised edition, Gulzow, 2010.

12.V. NIKOLIC, T. VINTILA, Producerea si utilizarea biogazului pentru obinerea de energie, (Production and utilisation of biogas to obtain energy), Editura Mirton, Timisoara, 2009.

13.H. HAHN, Intelligent Energy Europe Project, BiogasIn, Guideline for financial agricultural biogas projects, Fraunhofer IWES, 2011. 14.*** EC Directive, Directive 2012/27/EU of the European Parliament and of the Council of 25 October 2012 on energy efficiency, amending Directives 2009/125/EC and 2010/30/EU and repealing Directives 2004/8/EC and 2006/32/EC, L 315/1, Official Journal of the European Union, Brussels, (2012).

15.A. R. WACHTER, I. IONEL, T. VINTILA, D. VAIDA, Increasing energy efficiency of an agro-industrial integrated process through anaerobic co-digestion of slaughterhouse waste water and farm manure, Proceedings of 25th European Biomass Conference and Exhibition, 12-15 J une, Stockholm, Sweden, 938-942, 2017.

16.BOBOESCU, I.Z., GHERMAN, V.D.,MIREL, I.,MAROTI, G., NEGREA, A., Development of a two-step fermentative bio-hydrogen production process using selectively enriched microbial populations as inoculums, Rev. Chim. (Bucharest), 64, no. 8, 2013, p. 919-924

17.C. DIGUTA, J. STEFANA, F. ISRAEL-ROMING, M. BRULE, M. MUKENGELE, A. LEMMER, H. OECHSNER, Studies concerning enzymatic hydrolysis of energy crops, Romanian Biotechnological Letters, Vol. 12, No. 2, 3203-3207, 2007.

18.M. MATIUTI, I. HUTU, D. DIACONESCU, C. 'ONEA, Rural pole for competitivity: a pilot project for circular bioeconomy, Studies and research in etnozootechny, animal biodiversity and bioeconomy, Vol. 1, 220-225, 2018.

19.NEAMT, I., IONEL, I., FLORESCU, C., Sewage sludge to energy. Possible strategies for Timisoara water treatment plant, Rev. Chim. (Bucharest), 63, no. 7, 2012, p.739-742

$\overline{\text { Manuscript received: } 15.12 .2018}$ 